\title{
Alternatives In Building A Video Collection
}

\author{
John S. Coleman
}

The relative affordability of both home-type video cassette recorders (VHS and Beta) and the professional, U-matic or three-quarter inch, recorder has led to their acquisition by many academic libraries/media centers in recent years. The basic unadorned home unit can be had from discounters for less than $\$ 600$ in some cases, while the U-matic unit is available for around $\$ 1400$ on state contract.

\section{Uses of Video Recorders In an Academic Setting}

Aside from producing programs with a camera, there are two basic uses for the video recorder in an academic setting. First, there is the "time shifting" capability which permits the user to record programs as they are broadcast and to replay them at someone's convenience. However, copyright considerations severely limit the institutional copying of much broadcast material, both from the commercial networks and public television. Additionally, even where "fairuse" permits the copying of broadcasts, the tapes generally must be erased shortly thereafter. So, for practical purposes, one cannot, at present, look to copying off-the-air as a method of building a permanent video collection. (However, the licensing of off-the-air taping by the Television Licensing Center may somewhat alter this situation in the future.)

The second, non-production use for video machines is the playing of prerecorded tapes. As the number of video units in the educational market has grown, so has the number of programs available on video tape. It is now quite Common for educational productions to be offered for sale in both film and video formats. The Public Broadcasting Service, as well as established audiovisual producers such as Time-Life and McGraw-Hill, offer whole catalogs of highquality video programming for sale, and occasionally for rent.

However, David B. Walch places the average per-minute cost of an educational video cassette at $\$ 7.58^{1}$ which works out to slightly more than $\$ 450$ for a sixty minute program. Simple calculations show that to purchase ten hours of programming at this rate, an investment of $\$ 4500$ would be necessary. Even if institutions could annually devote that sum to building a video collection (and certainly many smaller schools might find themselves hard-pressed to do so), it would be a somewhat slow process whose very slowness might dampen the enthusiasm of some potential users.

This paper will suggest two sources for obtaining free video programming appropriate for use in the liberal arts curriculum. "Free" here means that the only cost to the institution is for the blank video cassette onto which the material is copied. 


\section{The Federal Government As Audiovisual Producer}

The Federal government is the largest producer of audiovisual materials in the world. It is estimated that the production and distribution of films and video tapes in 1978 cost the government about $1500,000,000 .{ }^{2}$ The vast majority of these productions are not copyrightable because public funds supported their issuance. Therefore, after one had identified and located governmentproduced programs which seem to be potentially valuable additions to a collection, then it is often possible to obtain permission to copy them free of charge onto video tape. However, it should be noted that the National Audiovisual Center, the central agency for the distribtuion of government audiovisuals, is not helpful in this process beyond supplying information about the various agencies and departments which produce films and tapes. The Center does not supply free copies of materials for duplication. Nor does the Center act as a clearinghouse for copyright information. It is sometimes assumed that anything produced by the government is automatically in the public domain and can therefore be copied without hesitation. But, there are cases where the producing agency has used an outside producer, with the result that the copyright status of the program is uncertain at best. It seems prudent to contact the producing agency directly in order to get permission to copy and, hopefully, also to get a free copy which will serve as a master.

Many government productions are now available on tape as well as on film. However, older titles may be available only on film. Provided the material is on tape, it is a fairly simple matter to copy it from the original (usually on threequarter inch tape) onto a blank tape by using cable connections between two video machines. For example, the Department of Labor's series on labormanagement negotiations, Out of Conflict ... Accord consists of six tapes. Upon request, permission was granted to Wingate College to copy the approximately three hours of this award-winning series (winner of a Red Ribbon, American Film Festival). For the cost of one VHS cassette, about $\$ 15.00$, these tapes become part of a permanent collection available to the Business and Economics faculty and students. Likewise, portions of the National Institutes of Health's Series called Medicine for the Layman have been duplicated.

In cases where only film versions are available, the copying process is somewhat more complicated. The permission-seeking and searching for a free master remains the same. But, the mechanics of transferring from sixteen millimeter film to video tape is considerably more involved. In addition to a video recorder, one generally needs at least three other pieces of equipment. They are: 1) a $16 \mathrm{~mm}$ film projector which has had a five-blade shutter installed so as to minimize the flicker produced when the camera is aimed at a film image on the screen. The cost of having a projector modified is in the $\$ 50-\$ 60$ range, including the cost of the shutter; 2) a special screening device which accepts the image from the projector and relays it onto a mirror from which the video camera picks it up. A number of companies market such devices at about $\$ 100$, including JVC which calls its device a "Tele cine." One can circumvent the necessity for this 
piece of equipment by simply recording the film image directly from a conventional screen, but this practice seems less satisfactory; 3 ) obviously, some kind of camera is necessary, and equally obvious is the fact that the greater is the resolution capability of the camera, the better the finished product will be, all other factors being equal.

Wingate College obtained the right to duplicate a series of four films produced by the Department of State and used the equipment described above. The series is the History of U.S. Foreign Relations which has uses in both the history and political science curricula. Available for sale from the National Audiovisual Center, the series can be rented from a number of the larger educational film libraries across the country, attesting to its quality. The tapes produced from these films are not equal in quality to the copies produced from tape masters, but they are acceptable.

To learn what is available from the government, consult the National Audiovisual Center's Reference List of Audiovisual Materials Produced by the United States Government (1978) and a 1980 Supplement. Also, request to be put on the NVAC's mailing list to receive informaiton on new productions. In looking over the list of government films and tapes, it becomes clear that the vast majority of the programs are of no interest for the purposes under discussion here. But, a judicious selector can probably identify titles which have a place in a video collection, given the diversity of subjects covered by government producers.

\section{The Free-Loan Film}

Another potential source of free programs is the sponsored or free-loan film. Distributed by organizations such as the Modern Talking Picture Service, sponsored films generaily fall into one of two categories. The majority are sponored by a company or an industry group with the aim of drawing attention to their product, service, or point of view. An example of this type of film is TreesThe Endless Harvest which is sponsored by the St. Regis Paper Company. Programs of this sort are obviously not of much interest in this discussion.

The other type of sponsored film contains no "advertising," overt or otherwise, and can be useful in building a collection. For example, the Exxon Corporation has underwritten a number of high-quality productions such as The Eye of Thomas Jefferson, In Rehearsal: The New Conductors, and Of Time, Tombs, and Treasure: The Treasures of Tutankhamun. Upon application, Exxon granted a limited license to Wingate to make a video tape copy of these three. Since the film sponsors' interest lies in getting as large an audience as possible for their films, they are often amenable to granting permission to copy. However, as with government films, one needs to apply directly to the sponsor. The distributors cannot give permission for duplication.

There are two approaches for locating these sponsored films. One is to check published guides to free educational materials such as the Educators Guide to Free Films and NICEM's Index to Free Educational Materials- 
Multimedia. Simply looking through the catalogs of free film distributors is another approach. A sampling of these distributors includes: Modern Talking Picture Service (5000 Park Street North, St. Petersburg, Florida 33709), Association Films, Inc., (866 Third Avenue, New York, New York 10022), Karol Media (625 From Road, Paramus, New Jersey 07652), and Audience Planners, Inc. (One Rockefeller Plaza, New York, New York 10020).

Certainly, the copying of free programs will not, by itself, provide a solution to the dilemma posed by the high cost of pre-recorded educational video tapes. As has been emphasized here, the vast majority of free materials simply have no application for serious educational use. But, if one applies the same selection criteria, in consultation with the appropriate faculty, that would be applied to any non-print media, then this approach would seem to offer some promise as a supplemental aid.

John S. Coleman was formerly reference and audiovisual librarian, Wingate College Library, Wingate, N.C. He is presently assistant professor and director of the audiovisual center, Washington and Lee University, Lexington, $\mathrm{Va}$.

\section{References}

1. David B. Walch, "Price Index For Nonprint Media," Library Journal 106 (February 15, 1981): 433.

2. "H. R. 9657; More on Government-Produced AVMaterials," EPIEgram: Materials 7 (October 30, 1978): 2 .
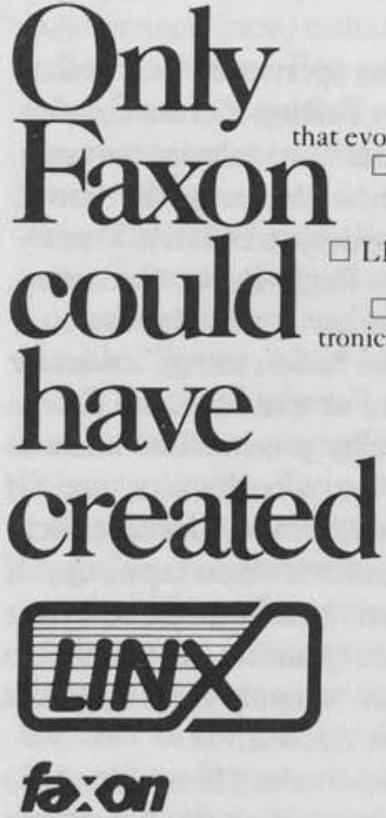

The superior serials management system hat evolves with your changing needs. $\square$ DATALINX for direct access to computerized Faxon data bases and files. LINX SC-10 for on-line check-in and claiming. $\square$ LINX for instantaneous electronic messages and comprehensive. on-line training.
Get the complete story on LINX.

There's no competition!

Mail coupon to:

Faxon

15 Southwest Park

Westwood, Massachusetts 02090 USA

Tel: 800-225-6055 (toll-free) 617-329-3350 (collect in Mass. and Canada)

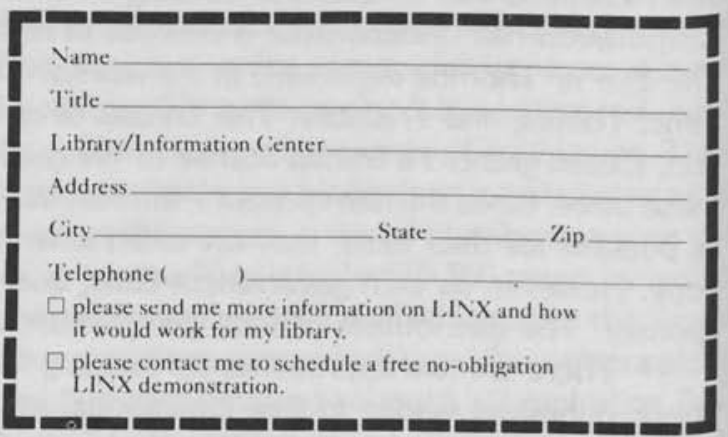

